\title{
Pedagogical Challenges of ESP Teachers in Albania
}

\author{
PhD Candidate. Mirjeta Cenaj
}

\author{
Sports University of Tirana, Department of Social Sciences and Education
} Email: mirjetacenaj@yahoo.com

\section{Doi:10.5901/ajis.2015.v4n3s1p489}

\begin{abstract}
The aim of the present study is to identify past and present pedagocical challenges that ESP teachers face in Albania. The data was gathered through an online survey composed of 15 questions through which were identified different aspects of ESP teachers' job in some higher education institutions in Albania. The identified issues were partly expected as there are no educational specilised courses offering training and formation of ESP teachers, instead they have been mostly trained and graduated as GE teachers and have taken personal and private training to accomodate their teaching skills into the setting of a specific institution where they teach English to students of specific fields with specific needs imposed by the field of study and professional requirements needed for future employment. Apart pedagocical issues ESP teachers have to deal with linguistic challenges at the start of their job because they might have limited knowledge of the core subjects and key terminology characterizing that branch of study whose students the teacher is teaching. Thus, many challenges and issues, both pedagogical and lingustic, were identified as well as some recomandations were given by the 18 teachers and lecturers who responded the survey.
\end{abstract}

Keywords: pedagogical challenges, linguistic issues, ESP teachers.

\section{Introduction}

The English language learning has become a priority in the long-term prospective of the Ministry of Education in Albania this reflected also in the fact that English or other foreign language classes are offered to pupils from the $3^{\text {rd }}$ grade up to the final year at high school. From 2015 foreign language is a mandatory exam at the end of the $12^{\text {th }}$ grade (CEFR B1 level), while a considerable percentage of students choose English as an elective exam at the end of this cycle (B2 level) and it will be one as well for pupils ending the low middle school at the end of $9^{\text {th }}$ grade (A1 level). This provides the basis of a nationwide standardized testing of the first foreign language of students at the final examinations before enrolling at university. Based on the fact that the majority of the students belong to B1 level of language proficiency lays the ground for language teachers at university to design and deliver ESP classes. When they attend higher education students attend English classes for 1 up to 3 semesters in most of the universities within Albania. These are mainly ESP classes but general English classes are still taught at some faculties or universities. These classes aim mainly to improve further their general foreign language skills but also to introduce field specific text and genre as well as vocabulary in order to prepare these students to the demands of their future profession and labor market. In this context, the problem that rises is that of training of ESP teachers as all of them are graduated mainly as EFL teachers and the majority of them teaching the ESP classes lack a proper training as ESP teachers. Thus, GE teachers who now teach ESP classes have encountered and still face many situational as well as methodological problems.

\section{Research Objectives}

This study aims to identify some of the issues faced by ESP teachers in Albania, the issues on focus here are common for ESP teachers worldwide as such confirmed by many studies carried out by different researchers in many countries .

Through a questionarie delivered electronicaly to many English teachers, but to which only 18 responded the present study aims to:

1 - Identify the challenges that ESP teachers met at the start of their job at the respective HEI

2 - Identify which issues they are facing at present

3 - Investigate some common problematic aspects of ESP teaching in Albania through the responses submited by teachers

4 - Summerizes some sugestions the teachers have provided on how to overcome these difficulties 


\section{Theoretical Framework}

The problems mostly encountered by ESP teachers, as studied and identified as well as explained by many researchers and scholars of the field such as Hutchinson \& Waters, Dudly Evans \& St.John, Chambers etc, vary from needs analyses to curriculum development and appropriate teaching materials design and use.

It is no surprise that at the start of their profession ESP teachers state to have had difficulties in analysing students' needs as this issue is identified and explained by some scholars of this field. Some reasons why needs analyses is challenging are such as: students do not have a clear prediction of the future needs they will face in their occupation setting (Long, 1996), the level of motivation of students may also disorient the teacher for their immediate or present language needs for example in the case of EAP students (Chambers, 1980). If the needs analyses is not accurate this affects the setting of the objectives and consequantely the choice of proper teaching strategies and methodology, course content which on the other hand may demotivate the learners and consequently the course will not meet their expectations and real immediate or future needs.

Another reason they encounter problems is that they lack ESP training or related courses on ESP methodology as the majority of them have finished university at a time when this subject was not part of the curricula. Currently, undergraduate students and future GE teachers are taught a subject on ESP at the respective faculty. This lack of training makes them come across situations and issues they cannot cope with because as Hutchinson and Waters (1987) explain ESP teachers are in: "... a new environment for which they have generally been ill-prepared."

What makes ESP teaching challenging is also the fact that an ESP teacher, called 'practitioner' by Dudley-Evans and St John (1998), has many roles to play. An ESP teacher is not only a FL teacher but he/she is also a syllabus designer, course content developer, teaching materials designer, evaluator, collaborator as well as a researcher. This multifaceted role of the teacher's job of course makes it demanding and challenging.

\section{Findings and Discussion}

The data was gathered through an online survey composed of 15 questions through which were identified different aspects of ESP teachers' job in some higher education institutions in Albania. The data gathered from the questionnaire were processed using SPSS package.

The number of respondent teachers is 18 , and $72 \%$ of them teach ESP (chart 1).

Chart 1: Percentage of GE or ESP teachers.

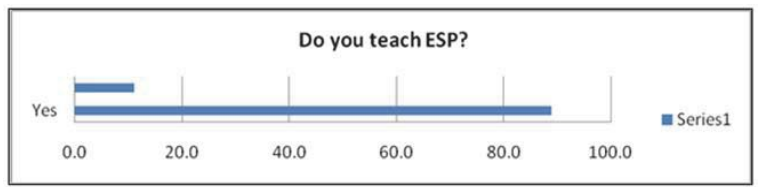

$39 \%$ of them have been in ESP teaching for $5-10,28 \%$ for $1-5,22 \%$ for 10-15 years (chart 2). As the responses show the majority of the teachers subject of this survey do teach ESP and have experience as ESP teachers, 7 or $39 \%$ of them have been teaching ESP for 5 to 10 years, and 6 of them have a longer experience more than 10 years ( 4 teachers have taught for $10-15$ years and 2 of them for more than 15 years).

Chart 2: The number of years in ESP teaching.

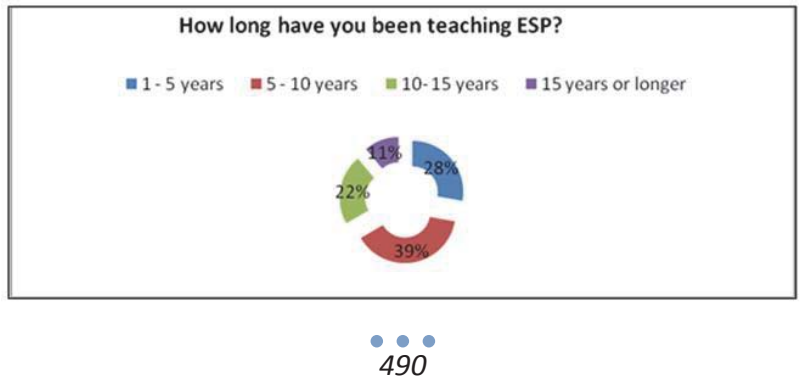


As it is reflected in the teachers' responses (chart 3 below) they have encountered and still face problems, such as: students' needs analyses, relevent course content and material selection and use, designing or developing new or existing teaching materials, employing methodology, students' motivation as well as feedback. They also state that using $\mathrm{A} / \mathrm{V}$ aids in the language classroom is problematic or difficult for them at present maybe due to lack of facilities and proper inrastructure. In the past the dominant problem was finding out and analysing students needs but it seems that with the passing of time and the gained experience they have overcome the problem.

While at present the aspect which they have chosen as more challengng is the selection and use of relevant class materials. This could be due to the dilema whether to use general English materials or field specific and authentic materials, eventhough they strongly support the idea of using specific content materials (chart 5), which some of the teachers might have difficulty to understand them as their are highly technical text and need expertise knowledge of the key cocepts of the field and the language teachers are not at ease in this context.

Chart 3: Past and present issues.

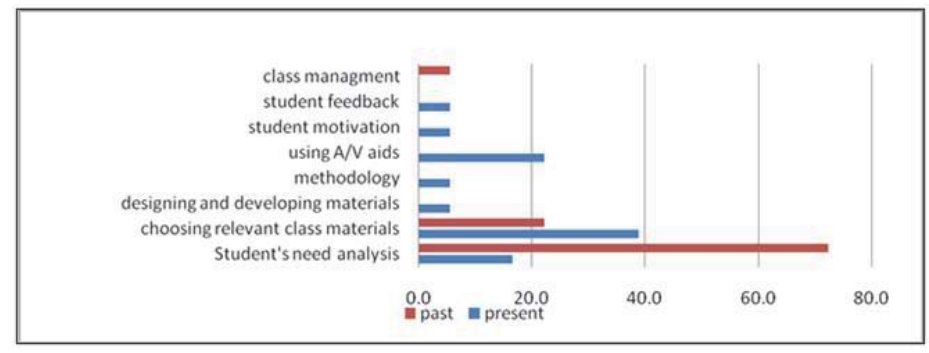

All these problematic issues could be due to lack of ESP training, as $83.3 \%$ (chart 4 below) of the asked teacher do not have one, even though as ESP has gained ground now there's an ESP subject taught to future teachers at university, another reason is unfamiliarity or lack of deep understanding of the core subjects or field of study which makes it difficult for them to explain the field specific language without a deep understanding of the concepts of it, they are not at ease when it comes to using authentic materials, even though knowledge of the field was not a requirement at the start of their job it could have been very helpful. A way to cope with this problem is to consult with professors of the core subjects as $66 \%$ (chart 4) of the respondents do. ESP teachers bridge the gap of lack of specific field knowledge and field terminology by consulting the specialists of the respective fields in order to accommodate themselves in a field of expertise which they do not master.

Chart 4: Teacher's perceptions.

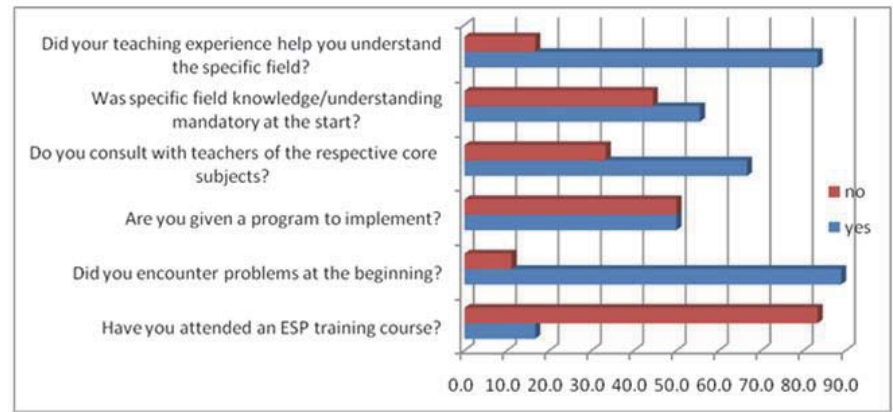

Other perceptions brought to light through this questionnaire (chart 4) are: the majority of teachers encountered problems at the start of their job as ESP teachers and at almost the same percentage they say that they have not attended and ESP training course; as mentioned earlier, a source of problems is the fact that ESP teachers have many roles to play and many duties to accomplish at the same time as it is the lesson plan and program that they have to design and 
implement, and before reaching this stage they have to identify and analyze students' needs, make decisions as regarding classroom materials, vocabulary selection and teaching strategies to satisfy these needs and to improve their language skills and prepare them for their profession.

Other issues presented by teachers through an open question are: lack of infrastructure or A/V equipment, lack of terminological dictionaries to foster independent learning, finding and using strategies to practice in and out of the class, and difficulty in finding appropriately tailored resources for some specific fields. Another challenge they have to overcome is also the large number of students in classes often students with heterogonous abilities and needs and when this adds on de-motivation because of difficult or uninteresting materials makes the gap deeper and wider.

The majority of the respondents, $94.4 \%$ agree that pre or in-training ESP courses would make their teaching easier and help them cope with problems at the start as well as enable them to be efficient and innovative in the course of their teaching.

Chart 5: Teachers' suggestions

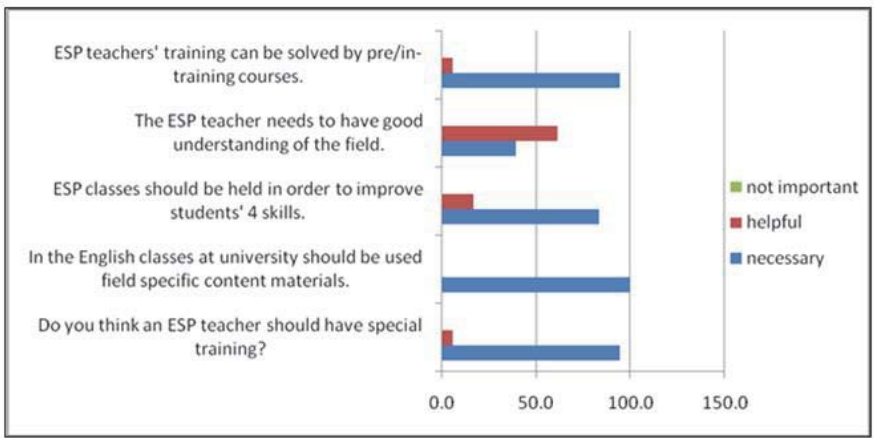

83.3\% the teachers (chart 5) agree that it is necessary that the ESP course improves the four language skills and at the same time it needs to introduce the students to the genre of texts and language features of their field of study through field specific content materials. In order to teach ESP classes they think that they need to develop a good understanding of the field form which they are selecting and using authentic or tailored class materials.

Obviously the majority of the teachers (94\%) support the idea that ESP teachers need to have special training and that can be solved through pre-training or in-training courses.

\section{Conclusion}

The findings of this survey can be summarized as following:

The identified challenges that the ESP teachers in Albania faced at the start of their teaching experience concern mainly students' needs analyses, followed in percentage by the choice and use of relevant class materials and class management. The first two aspects are still felt by the teachers and apart from them they also face problems such as the use of A/V aids, student feedback and motivation as well as issues of ESP methodology and the design of classroom materials.

Despite all the issues and challenges, both pedagogical and linguistic, they face in the course of their ESP teaching, the teachers agree that ESP classes are important to be delivered to university students, moreover they fully agree that the classroom materials should be of field specific content in order to prepare the students to the requirements of their academic life and demands of their future profession.

The teachers subject of this survey suggest that the identified and perceived problems they have faced and still encounter are mainly due to lack of prior training as ESP teachers thus they could be overcome through pre or in-training for this sub-division of English teaching in order to have appropriately and fully trained ESP teachers. 


\section{References}

Chambers, F. (1980). A re-evaluation of needs analysis. ESP Journal, 1/1

Dudley-Evans, T., and St John, M. (1998). Developments in ESP: A multi-disciplinary approach. Cambridge: CUP.

Hutchinson, Tom \& Waters, Alan. (1987) English for Specific Purposes: A Learning Centered Approach. Cambridge: Cambridge University Press.

Long, M. (1996). The Role of the Linguistic Environment in Second Language Acquisition. In W. Ritchie \& T. Bhatia (eds), Handbook of Second Lang-uage Acquisition, 413-68. San Diego: Academic Press. 